\title{
Nursing: promoting the health of overweight children and adolescents in the school context
}

\author{
ENFERMAGEM: PROMOÇÃO DA SAÚDE DE CRIANÇAS E ADOLESCENTES COM \\ EXCESSO DE PESO NO CONTEXTO ESCOLAR
}

\section{ENFERMERÍA: PROMOCIÓN DE LA SALUD EN NIÑOS Y ADOLESCENTES CON SOBREPESO EN EL CONTEXTO ESCOLAR}

\section{Nathalia Costa Gonzaga ${ }^{1}$, Thelma Leite de Araújo² ${ }^{2}$, Tahissa Frota Cavalcante ${ }^{3}$, Francisca Elisângela Teixeira Lima ${ }^{4}$, Marli Teresinha Gimeniz Galvão ${ }^{5}$}

\begin{abstract}
The study aimed to analyze the nursing interventions related to the competencies of health promotion of overweight children and adolescents in the school context, in light of the Galway Consensus through an integrative review. Articles published between 1988 and June, 2013 were found in the databases CINAHL, SCOPUS, MEDLINE/ PubMed, Cochrane, LILACS and SCIELO. A total of 139 publications were obtained from indexed descriptors. Ten articles were selected after reading. The most evident competencies for health promotion were: catalyzing change, needs assessment and impact assessment. The highlights were activities of health education and partnerships with other health professionals and the families of students. It was found that the skills of health promotion developed by nurses can contribute to the adoption of healthy habits by overweight children and adolescents.
\end{abstract}

\section{RESUMO}

Estudo com o objetivo de analisar as intervenções de enfermagem relacionadas às competências de promoção da saúde de crianças e adolescentes com excesso de peso no contexto escolar, à luz do Consenso de Galway, por meio de uma revisão integrativa. Foram encontrados artigos publicados entre o ano de 1988 e junho de 2013, nas bases de dados CINAHL, SCOPUS, MEDLINE/PubMed, Cochrane, LILACS e SciELO. A partir de descritores indexados, obtiveram-se 139 publicações. Após leitura, foram selecionados 10 artigos. As competências de promoção da saúde mais evidenciadas foram: catalisar mudanças, avaliação das necessidades e avaliação do impacto. Destacaram-se as atividades de educação em saúde e as parcerias com outros profissionais de saúde e as famílias dos estudantes. Verificou-se que as competências de promoção da saúde desenvolvidas por enfermeiros podem contribuir para a adoção de hábitos saudáveis por crianças e adolescentes com excesso de peso.

\section{DESCRITORES}

Cuidados de enfermagem

Obesidade

Saúde escolar

Promoção da saúde

Revisão

\section{RESUMEN}

Este estudio tuvo como objetivo analizar las intervenciones de enfermería relacionadas con las competencias para la promoción de salud de los niños y adolescentes con exceso de peso, en el contexto escolar, de acuerdo con el Consenso de Galway, a través de una revisión integradora. Se encontraron artículos publicados entre 1988 y junio 2013, en las bases de datos CINAHL, SCOPUS, MEDLINE/PubMed, Cochrane, LILACS y SciELO. A partir de los descriptores indexados, se obtuvieron 139 publicaciones. Después de su revisión, fueron seleccionados 10 artículos. Las competencias para la promoción de salud fueron: catalizar el cambio, evaluación de necesidades y evaluación de impacto. Se destacaron las actividades de educación para la salud y la colaboración con otros profesionales de salud y con las familias de los estudiantes. Así, se constató que las competencias para la promoción de salud desarrollada por los enfermeros pueden contribuir a la adopción de hábitos saludables por los niños y adolescentes con exceso de peso.

\section{DESCRIPTORES}

Atención de enfermeira

Obesidad

Salud escolar

Promoción de la salud

Revision 


\section{INTRODUCTION}

Overweight in children and adolescents is as a worldwide epidemic ${ }^{(1)}$, which reflects changes occurred in the lifestyle of society, especially regarding diet and physical activity ${ }^{(2)}$.

In this age group, excess weight is a risk factor for many early and/or late alterations ${ }^{(3)}$, such as: psychosocial disorders, depression, isolation, low self-esteem, respiratory and orthopedic disorders, hypertension, diabetes, dyslipidemia, metabolic syndrome, cardiovascular disease and cancer ${ }^{(4-6)}$.

Considering the magnitude of the problem, strategies of health promotion should be implemented to reverse this trend ${ }^{(7)}$. In this context, health policies recognize schools as privileged spaces for practices of health promotion, preventive and of health education ${ }^{(8)}$.

In Brazil, the School Health Program (PSE - Programa Saúde na Escola) established in 2007, resulted in the articulation between Schools and Primary Health Care through the Family Health Program (ESF - Estratégia de Saúde da Família). The PSE consists of eight guidelines and aims at contributing to strengthen actions in view of the overall development and provide that school communities participate in programs and projects that combine health and education, to cope with vulnerabilities that compromise the full development of children, adolescents and young people from public schools. In this program, it is worth noting the anthropometric assessment in component $\mathrm{I}$, which aims to identify students with overweight and obesity, and in component II, the actions of promoting healthy eating and physical activity in schools ${ }^{(8)}$.

The work of nursing in the school environment is critical to implement actions of primary prevention to control obesity through educational activities, as well as to identify overweight and treat this condition in children and adolescents. To achieve these measures, it is recommended that nurses work collaboratively with teachers and other educators in the community, besides creating partnerships with parents in order to assist them in promoting the health of their children ${ }^{(2)}$.

In order for the care directed at promoting the health of children and adolescents with excess weight to be effective, it is necessary that nurses incorporate specific competencies. The Galway Conference held in Ireland in June 2008, aimed at the global exchange and collaboration between countries, with the objective to identify and build core competencies in health promotion and education, as well as developing the workforce ${ }^{(9-10)}$.

The Galway Consensus has values and principles, a common definition and eight core domains of competency required for effectively engaging in practices of health promotion. The domains are: 1. Catalyzing change; 2. Leadership; 3. Needs assessment; 4. Planning;
5. Implementation; 6. Impact assessment; 7. Advocacy and 8. Partnerships ${ }^{(9-10)}$.

Within this context arose the following inquiry: What have been the nursing interventions related to the competencies of health promotion of overweight children and adolescents in the school context?

Given that this is a broad issue that demands studies, it was decided to search for answers in the literature, considering the need to analyze the concerns of researchers about this theme. The answer to this question can contribute to a critical reflection of nursing care practice in the health promotion of overweight children and adolescents, aiming to improve the performance of nurses. Thus, the aim of this study was to analyze the nursing interventions related to the competencies of health promotion of overweight children and adolescents in the school context.

\section{METHOD}

This is an integrative review, a method that aims to gather and synthesize research findings on a defined topic or issue in a systematic and orderly manner, thereby contributing to a deeper understanding of the investigated subject ${ }^{(11)}$.

To reach the proposed goal, the steps below were followed: (1) identification of the problem or issue (drafting the guiding question, establishing descriptors); (2) establishing inclusion/exclusion criteria for articles (articles selection); (3) categorization of studies according to the competencies; (4) defining the information to be extracted from selected papers; (5) analysis and discussion; (6) synthesis of findings evidenced in the analyzed articles ${ }^{(12)}$.

Inclusion criteria for the selection of publications were: having as the theme of research the nursing interventions aimed at overweight children and adolescents; being available electronically, in full and for free; being classified as an original article, experience report, reflection or systematic review; being indexed in at least one of the following databases: Cumulative Index of Nursing and Allied Health Literature (CINAHL), SCOPUS, National Library of Medicine and National Institutes of Health (MEDLINE/PubMed), Scientific Eletronic Library Online (SciELO), Cochrane or LILACS Literature in the Health Sciences in Latin America and the Caribbean (Literatura Latino-Americana e do Caribe em Ciências da Saúde). Editorials, letters to the editor and duplicates, ie articles already available on a formerly used base were excluded.

For the age group criterion, the World Health Organization (WHO) recommendations were followed. Therefore, the articles who reported nursing interventions for preschool children (2-5 years), school children (6-9 years) and adolescents (10-19 years) were included ${ }^{(13)}$.
Nursing: promoting the health of overweight children and adolescents in the school context Gonzaga NC, Araújo TL, Cavalcante TF, Lima FET, Galvão MTC 
In relation to anthropometric criteria, overweight and obesity are defined as abnormal or excessive accumulation of body fat. Both represent the phenomenon of overweight but obesity is a more advanced stage. According to the $\mathrm{WHO}$, in adults a body mass index (BMI) value $\geq 25$ is considered overweight and values $\geq 30$ are considered obesity ${ }^{(14)}$. There are different reference curves for the anthropometric assessment of children and adolescents ${ }^{(15-17)}$. As questions still persist as to the best diagnostic criteria of overweight and obesity in this age group, this review did not aim to exclude or include articles according to the standards used by the authors.

The collection of articles was carried out in June 2013, using the following controlled descriptors from Bireme - Biblioteca Virtual em Saúde (Virtual Health Library) in
SCIELO and LILACS: enfermagem AND (obesidade OR sobrepeso) AND (pré-escolares OR criança OR adolescente) AND promoção da saúde AND (saúde escolar OR serviços de saúde escolar OR serviços de enfermagem escolar). The MeSH (Medical Subject Headings) descriptors were inserted into the bases CINAHL, Scopus, PubMed, Cochrane and LILACS: nursing AND (obesity OR overweight) AND (child, preschool OR child OR adolescent) AND health promotion AND (schools OR school nursing).

From the pool of descriptors, a total of 139 articles published between 1988 and June 2013 were found. Initially, titles and abstracts were read and assessed according to the inclusion and exclusion criteria. After this stage 66 articles were read in full, 10 of which met the inclusion criteria (Table 1).

Table 1 - Distribution of articles found and selected - Fortaleza, CE, 2013

\begin{tabular}{cccccccc}
\hline Articles/Base & PubMed & CINAHL & SCOPUS & Cochrane & SciELO & LILACS & Total \\
\hline Found & 44 & 37 & 53 & 5 & 0 & 0 & 139 \\
Excluded & 41 & 32 & 51 & 5 & 0 & 0 & 129 \\
Selected & 3 & 5 & 2 & 0 & 0 & 0 & 10 \\
\hline
\end{tabular}

Justifications for exclusions: 22 articles electronically unavailable (nine in MEDLINE/PubMed, five in CINAHL, three in SCOPUS and five in Cochrane); an editorial (MEDLINE/PubMed); a summary of congress (CINAHL); 56 for not answering the research question; and 49 were duplicates.

The articles were classified according to the level of scientific evidence ${ }^{(18)}$ and the study results were showed in tabular form and analyzed according to the eight competency domains for the practice of health promotion defined in the Galway Conference and published by various authors ${ }^{(9-10)}$. Data analysis demanded translation, reading and rereading of the articles. It was carried out in a descriptive and analytical way as the data were discussed based on the competencies of the core domains.

\section{RESULTS}

Among the ten selected articles - all published after 2005 - seven are from the United States ${ }^{(19-25)}$, two from European countries (Sweden and Denmark) ${ }^{(26-27)}$ and one from Taiwan ${ }^{(28)}$. According to the classification of levels of evidence of the studies ${ }^{(18)}$, nine were classified as level $\mathrm{VI}^{(19-20,22-28)}$ and only one as level of evidence $\|^{(21)}$. The distribution of articles according to competency domains and nursing interventions is showed on chart 1 below.

Chart 1 - Distribution of articles according to competency domains and nursing interventions - Fortaleza, CE, 2013

Domain 1: Catalyzing change

- Nurse-patient relationship ${ }^{(20,25,27)}$

- Activities designed to promote healthy habits ${ }^{(20)}$

- Empowerment ${ }^{(25,27)}$

- Health education ${ }^{(20,24)}$

- Family-centered care ${ }^{(25)}$

- Counseling ${ }^{(24)}$

Domain 3: Needs assessment

- Knowledge of the reality of families ${ }^{(25)}$

- Assessment of the psychosocial context (stress and anxiety)(20)

- Identification of cardiovascular risk factors other than obesity. Example: hypertension and physical inactivity ${ }^{(24)}$

- Assessment of the lifestyle ${ }^{(25)}$

- Identification of barriers to treatment ${ }^{(25)}$

- Assessment of nutritional category perceived by individuals themselves ${ }^{(22}$

- Assessment of the psychosocial context (bullying and suicide attempts) ${ }^{(22)}$

- Evaluation of weight loss attempts ${ }^{(22)}$

- Evaluation of weight loss attempts ${ }^{(22)}$

- The use of self-assessments of motivation ${ }^{(25)}$ 
Domain 4: Planning

- Planning of the healthcare team to promote health ${ }^{(20)}$

- Planning of viable strategies for treatment ${ }^{25)}$

- Use of theoretical frameworks in care planning ${ }^{(24)}$

Domain 5: Implementation

- Teamwork ${ }^{(21,28)}$

Domain 6: Impact assessment

- Evaluation of health promotion activities ${ }^{(19,23-24,26,28)}$

- Evaluation of the difficulties and barriers to the implementation of health promotion interventions ${ }^{(23)}$

- Evaluation of the intervention results ${ }^{(21,27)}$

Domain 8: Partnerships

- Partnerships with other health professionals ${ }^{(20,24)}$

- Partnerships with nurses in a pediatric hospital ${ }^{(20)}$

- Partnerships with parents of students ${ }^{(20,25)}$

- Partnerships with families ${ }^{(24)}$

- Referral to the physical education sector ${ }^{(24)}$

The most evident domains were: catalyzing change, needs assessment and impact assessment. The domains of leadership and advocacy were not included in the articles. Six articles ${ }^{(20-21,24-25,27-28)}$ focused on more than one competency domain (Chart 1).

\section{DISCUSSION}

Although almost all studies had low levels of scientific evidence, the results included important nursing interventions to achieve health promotion of overweight children and adolescents in the school context. In most of the analyzed articles, stood out the intervention programs aimed at the adoption of healthy habits.

In this context, the National Policy for the Promotion of Health (Política Nacional de Promoção da Saúde)(29) puts to the health sector the challenge of building intersectoral agreements, such as with the Education sector, bearing in mind that children and adolescents stay at school for many hours a day. Furthermore, several authors claim that the school is a space conducive to learning and socialization and that obesity-related interventions in this environment can be effective in improving health behaviors, such as reducing caloric intake and increasing physical activity ${ }^{(30-32)}$.

The participation of nurses in health promotion of children and adolescents in the school context is such a positive strategy that in some countries, like the United States and England, there is a specialty known as School Nursing. School nurses are responsible for promoting students' success in the school environment by providing direct healthcare, tests and referrals, as well as interventions for prevention and health promotion ${ }^{(33)}$. In Brazil, this integration of nursing with schools has been addressed more recently, since the implementation of the School Health Program (Programa Saúde na Escola).
The use of the school space for actions of health education, an important tool for the development of autonomy and empowerment of individuals and communities ${ }^{(34)}$, was observed in some of the studies assessed ${ }^{(20,24)}$. The actions in this area are located in the domain catalyzing change, which focus on allowing changes and empowering individuals and communities to improve health ${ }^{(9-10)}$.

In this sense, health education has been seen as the most frequent activity for health promotion developed at school, where nurses carry meetings with students to address issues related to health ${ }^{(35)}$, such as being overweight.

Articles included in the review - which had activities of health education directed at overweight children and adolescents and their parents - were focused mainly on healthy eating. In the meetings were included photos and graphics of food labels, videos, discussions, games, taste testing and sharing of positive experiences ${ }^{(20,24)}$. The goal of one of the programs was to promote healthier eating habits, and a slow and gradual weight loss, accompanied by better choices and greater knowledge and awareness of children, adolescents and their families ${ }^{(20)}$.

In that same program, a weekly schedule was opened for a session carried out by nurses about changes in behavior with the following topics: body image, setting goals and rewards, coping with feelings, relaxation, meditation and yoga, positive thinking, problem solving and planning and support systems ${ }^{(20)}$. Health education should be inserted in the daily practice of nurses and these professionals must put themselves as educators, precisely by the reciprocal action of reflection with individuals, understanding that they do not own the knowledge, but rather cooperate and participate of this transformative process ${ }^{(36)}$.

The third domain relates to needs assessment and evaluation of communities resources and systems that lead to the identification and analysis of behavioral, cultural, 
social, environmental and organizational determinants that promote or compromise health ${ }^{(9-10)}$.

Among the articles that demonstrated nursing interventions in the domain called needs assessment, two addressed psychological issues: anxiety, stress, bullying and suicide attempts ${ }^{(20,22)}$. Therefore, it is necessary to search beyond the biological understanding, for the relationship of the psychological process with weight excess in children and adolescents. Understanding the excess of weight presupposes considering the fact that it is a multifactorial phenomenon involving aspects of organic, social, economic and psychological nature, among others, with consequences for both individuals and their environment ${ }^{(37)}$.

The inclusion of the family in the management of overweight tends to be a successful approach for needs assessment, as well as for planning and implementation. One of the studies included in the review ${ }^{(25)}$ carried out a familycentered approach in which the nurses chose to visit the families of children and adolescents in order to plan an intervention of negotiation. In these visits, the nurses assessed the health of children or adolescents and the motivation and confidence of parents in participating of the planning and achievement of the necessary goals for their behavioral change (measured on a scale from 0 to 10).

This dialogic relationship in which professionals, patients and families should understand that success depends on the shared negotiation, highlights the important role played by nurses in empowering the individual as a promoter of health ${ }^{(38)}$.

Given the above, comes the conclusion that the assessment is directly related to the fourth domain - planning - aimed at the development of measurable goals and objectives in response to the needs assessment and identification of strategies guided by the knowledge derived from theory, evidence and practice ${ }^{(9-10)}$. The highlight in this field is the relevance of using theoretical models for planning nursing interventions for health promotion.

The L.I.F.E. Program (Lifestyle Improvements in the Family Environment), described in a study ${ }^{(24)}$, is based on two theories: the Maslow's hierarchy of human needs ${ }^{(39)}$ and the Social Cognitive Theory. The first assumes that all human beings have common needs that motivate their behavior in order to reach satisfaction, and links these needs with a hierarchy. As human beings are always seeking satisfaction, when experiencing it at a given level, they then move to the next need and so on. In his theory, Maslow hierarchically classifies needs into five levels, namely: basic or physiological, safety, social, ego (esteem) and self-realization ${ }^{(40)}$.

The Social Cognitive Theory, on its turn, adopts the perspective of the agency for self-development, adaptation and change ${ }^{(41)}$. Being an agent means intentionally influencing one's own functioning and life circumstances. According to this view, people are self-organized, proactive, self-regulated and self-reflexive, contributing to the circumstances of their lives, hence not just a product of these conditions ${ }^{(42)}$.

In addition to these two theories, the L.I.F.E. program was influenced by the ecological perspective that emphasizes the concepts that the behavior both affects as it is affected by multiple levels of influence, such as: individual, interpersonal, organizational, community and public policy ${ }^{(43)}$. The program also adopted the Health Belief Model (perceived susceptibility and severity of the disease and perceived benefits and barriers with respect to the behavior of prevention or treatment of the disease)(44), the Stages of Change (precontemplation, contemplation, preparation, action and maintenance) ${ }^{(45)}$ and the PRECEDE-PROCEED Model. The latter provides a framework for planning a strategy of health promotion that starts with the desired results and evaluates the determinants of these outcomes through assessment, diagnosis, planning, implementation and evaluation of the process, impact and outcome ${ }^{(43)}$.

Implementation, the fifth domain, is the effective and efficient development of ethical and culturally sensitive strategies to ensure the highest possible level of health improvements, including the management of human and material resources ${ }^{(9-10)}$. In this respect, teamwork was an important nursing intervention identified. Teamwork aims to promote health and provide well-being and learning for participants in terms of solving difficulties and problems, also encouraging mutual support, with each one caring for oneself, for each other, the community and the environment ${ }^{(46)}$.

Impact assessment, the sixth domain, aims at determining the scope, effectiveness and impact of policies and programs to promote health. This includes the use of appropriate evaluation and research methods to support improvement, sustainability and dissemination programs ${ }^{(9-10)}$. Among the articles included in this review, seven assessed the impact of the implementation of nursing interventions on the health of children and adolescents as well as in relation to the barriers found in that process. The information obtained from this domain is important to guide nurses with planning of interventions.

In the construction and development of health programs at schools it is essential to have partners, because the implementation of these programs requires the participation of multiple actors and partners from different sectors ${ }^{(47)}$. Based on the eighth domain, partnerships, which, according to the Galway Consensus, is collaborative work among disciplines, sectors and partners to improve the impact and sustainability of programs and policies for health promotion ${ }^{(9-10)}$. Nursing interventions should be extensive to the families, teachers and other professionals working in institutions ${ }^{(48)}$.

This domain of health promotion has been shown in some studies that included the family in interventions, as 
well as nurses from a pediatric hospital and the sector of physical education, concluding that the multifactorial nature of obesity requires the participation of different professionals in its treatment.

Furthermore, it is noteworthy that the already established bond between teachers and students is essential to the promotion of health ${ }^{(49)}$. A recent study found that students aged 10 to 11 years have created a number of useful tools for health promotion under the guidance of the teacher. The authors concluded that empowered children and adolescents may assume the task of promoting health in the classroom ${ }^{(50)}$.

It's worth noting that two domains have not been identified in the articles: leadership and advocacy. Leadership is the targeting of strategies and opportunities for participating in the development of healthy public policies, mobilization and management of resources for health promotion and capacity building ${ }^{(9-10)}$. Although the ability to lead is recognized as a vital tool in the working process of nurses, which can assist them in the management of nursing actions and contribute to the formation of a cohesive and committed work team ${ }^{(51)}$, the meaning of leadership comprehended in the Galway Consensus was not found in the ten articles analyzed.

The advocacy of rights of patients and the community aims at improving the health and well-being when favoring important aspects of quality of life and health promotion $^{(9-10)}$. In relation to overweight children and adolescents and their families, this advocate role involves defending their interests and empowering them for self care and autonomy.

Growing evidence that the health of the population is influenced by broad social determinants indicates that nurses should be able to promote community empowerment. To achieve this objective, health advocacy and leadership are extremely valuable skills. For an effective practice of health promotion, it is necessary that nurses defend individuals and communities and advocate on their behalf, acting in defense of healthy public policies and creating supportive environments ${ }^{(52)}$.

In addition, nurses should encourage the participation of community leaders in health councils. From the perspective of Primary Health Care, nursing professionals are seen as facilitators of community participation in the health system and as providers of quality clinical care, exercising practices that promote the health right as a right of citizens, in line with the policies of Primary Health Care in the country ${ }^{(53)}$.

In Brazil, exercised in the form of the Family Health Program (ESF - Estratégia de Saúde da Família), the Primary Health Care has been occupying large technical and political space in the last 15 years and has emphasized the role of nursing leadership in health promotion, autonomy and citizenship. The Strategy envisages investments in collective actions and reconstruction of health practices from the interdisciplinarity and intersectoral management in a given territory ${ }^{(53)}$. In this sense, nurses play the roles of leadership and advocacy on behalf of the collective.

Given the above, the importance of integrating the knowledge of health promotion skills in the curricula of nursing courses is clear, in order to train nurses with capacity to act from an integral approach, transdisciplinary, equitable and focusing on the population in detriment of the biomedical model ${ }^{(54)}$.

Finally, it is noteworthy that the appropriation of school space is critical for the application of skills to promote the health of children and adolescents by nurses, targeting the full development of these individuals, especially those who are already overweight.

\section{CONCLUSION}

Ten articles on nursing interventions for health promotion of overweight children and adolescents in the school context were analyzed. It was found that the school is a privileged environment for health promotion since the access of children and adolescents is extensive. In addition, the inclusion of families was a strategy used by various authors.

The competency domains for the practice of health promotion more evident in the publications were: Catalyzing change, needs assessment and impact assessment. The domains of Leadership and Advocacy were not reported in none of the articles.

Only an article allowed the assessment of the impact of interventions, a randomized clinical trial. Other studies would be necessary to reach a deeper understanding of the effectiveness of nursing interventions directed at children and adolescents with weight excess in the domain of impact assessment.

With respect to the Partnerships domain, in articles in which nurses worked together with other health professionals there was no limitation of which actions were performed by each professional. When considering that the nurse developed the set of actions described in the article as a team member, it is possible that some activities have not had the participation of nurses. This fact constitutes one of the limitations of data analysis in this review.

Another limitation in the data analysis of this study is the lack of Brazilian studies that address the discussed issue. The analysis of articles published in other countries may have suffered cultural interference, since they live in another sociocultural reality, especially in relation to School Nursing.
Nursing: promoting the health of overweight children and adolescents in the school context Gonzaga NC, Araújo TL, Cavalcante TF, Lima FET, Galvão MTG 
It is noteworthy that, although no studies have been found in Brazil, Brazilian nurses have been working on promoting healthy habits for students, especially after the implementation of the School Health Program (Programa Saúde na Escola). To facilitate the access to articles resulting from researches in Brazilian schools, the descriptor 'school health' should be included.

\section{REFERENCES}

1. Hamel LM, Robbins LB, Wilbur J. Computer- and webbased interventions to increase preadolescent and adolescent physical activity: a systematic review. J Adv Nurs. 2011;67(2):251-68.

2. Christian BJ. Targeting the obesity epidemic in children and adolescents: research evidence for practice. J Pediatr Nurs. 2011;26(5):503-6.

3. Lloyd LJ, Langley-Evans SC, McMullen S. Childhood obesity and risk of the adult metabolic syndrome: a systematic review. Int J Obes (Lond). 2012;36(1):1-11.

4. Diaz-Melean CM, Somers VK, Rodriguez-Escudero JP, Singh P, Sochor O, Llano EM, et al. Mechanisms of adverse cardiometabolic consequences of Obesity. Curr Atheroscler Rep. 2013;15(11):364

5. Melo TR, Jansen AK, Pinto RMC, Morales RR, Morales NM, Prado MM, et al. Quality of life of caregivers of overweight or obese children and adolescents. Rev Esc Enferm USP [Internet]. 2011 [cited 2013 July 20];45(2):319-26. Available from: http://www.scielo.br/pdf/reeusp/v45n2/en_v45n2a02.pdf

6. Han JC, Lawlor DA, Kimm SY. Childhood obesity. Lancet. 2010;375(9727):1737-48.

7. Montoya C, Lobo ML. Childhood obesity: a Wilsonian concept analysis. J Pediatr Nurs. 2011;26(5):465-73.

8. Brasil. Ministério da Saúde; Secretaria de Atenção à Saúde, Departamento de Atenção Básica. Saúde na escola. Brasília; 2009. (Cadernos de Atenção Básica, 24).

9. Howze EH, Auld ME, Woodhouse LD, Gershick J, Livingood WC. Building health promotion capacity in developing countries: strategies from 60 years of experience in the United States. Health Educ Behav. 2009;36(3):464-75.

10. Barry MM, Allegrante JP, Lamarre MC, Auld ME, Taub A. The Galway Consensus Conference: international collaboration of the development of core competencies for health promotion and health education. Glob Health Promot. 2009;16(2):5-11.

11. Mendes KDS, Silveira RCCP, Galvão CM. Revisão integrativa: método de pesquisa para a incorporação de evidências na saúde e na enfermagem. Texto Contexto Enferm. 2008;17(4):758-64.
In the analyzed articles, it was found that the skills of health promotion developed by nurses can contribute to the adoption of healthy habits by overweight children and adolescents. It was observed, however, that the interventions did not adopt a specific systematization for the nursing approach or even an own taxonomy, which points to the need for research using the nursing knowledge.

12. Pompeo DA, Rossi LA, Galvão CM. Revisão integrativa: etapa inicial do processo de validação de diagnóstico de enfermagem. Acta Paul Enferm. 2009;22(4):434-8.

13. World Health Organization. Social determinants of health and well-being among young people: Health Behaviour in School-Aged Children (HBSC) study: international report from the 2009/2010 survey [Internet]. Copenhagen WHO Regional Office for Europe; 2012 [cited 2013 Oct 25]. Available from: http://www.euro.who.int/_data/assets/pdf_ file/0003/163857/Social-determinants-of-health-and-wellbeing-among-young-people.pdf

14. World Health Organization; Food and Agriculture Organization of the United Nations. Diet, nutrition and the prevention of chronic diseases: report of a Joint WHO/FAO Expert Consultation [Internet]. Geneva; 2003 [cited 2013 Oct 25]. Available from: http://whqlibdoc.who.int/trs/ who_trs_916.pdf

15. World Health Organization; WHO Multicentre Growth Reference Study Group. WHO Child Growth Standards: length/height-for-age, weight-for-age, weight-for-length weight-for-height and body mass index-for-age: methods and development [Internet]. Geneva; 2006 [cited 2013 Oct 25]. Available from: http://www.who.int/childgrowth/standards/technical_report/en/

16. Kuczmarski J, Ogden CL, Guo SS. 2000 CDC growth charts for the United States: methods and development [Internet]. National Center for Health Statistics, Vital Health Stat; 2002 [cited 2013 Oct 25]. Available from: http://www.cdc. gov/growthcharts/2000growthchart-us.pdf

17. Hamill PV, Drizd TA, Johnson CL, Reed RB, Roche AF, Moore WM. Physical growth: National Center for Health Statistics percentiles. Am J Clin Nutr. 1979;32(3):607-29.

18. Melnyk BM, Fineout-Overholt E. Evidence-based practice in nursing and healthcare: a guide to best practice. Philadelphia: Lippincott, Williams \& Wilkins; 2011.

19. Jain A, Langwith C. Collaborative school-based obesity interventions: lessons learned from 6 southern districts. J Sch Health. 2013;83(3):213-22. 
20. Broussard L, Bryan C, Bellar D. Kids on the Geaux: an interdisciplinary, community-based child weight management program. NASN Sch Nurse. 2012;27(2):72-5.

21. Hendy HM, Wiliams KE, Camise TS. Kid's Choice Program improves weight management behaviors and weight status in school children. Appetite. 2011;56(2):484-94.

22. Lenhart CM, Daly BP, Eichen DM. Is Accuracy of weight perception associated with health risk behaviors in a diverse sample of obese adolescents? J Sch Nurs. 2011;27(6):416-23.

23. Morrison-Sanderberg LF, Kubik MY, Johnson KE. Obesity prevention practices of elementary school nurses in Minnesota: findings from interviews with licensed school nurses. J Sch Nurs. 2011;27(1):13-21.

24. Northrup KL, Cottrell LA, Wittberg RA. L.I.F.E.: A schoolbased heart-health screening and intervention program. J Sch Nurs. 2008;24(1):28-35.

25. Tyler DO, Horner SD. Collaborating with low-income families and their overweight children to improve weight-related behaviors: an intervention process evaluation. J Spec Pediatr Nurs. 2008;13(4):263-74.

26. Magnusson MB, Kjellgren $\mathrm{KI}$, Winkvist A. Enabling overweight children to improve their food and exercise habits - school nurses' counseling in multilingual settings. J Clin Nurs. 2012;21(17-18):2452-60.

27. Borup IK, Holstein BE. Overweight children's response to an annual health dialogue with the school nurse. Int J Nurs Pract. 2010;16(4):359-65.

28. Chen MY, Chou CC, Hsu CY. The experiences of overweight female adolescents after health promotion counseling. J Nurs Res. 2005;13(1):41-8.

29. Brasil. Ministério da Saúde; Secretaria de Vigilância em Saúde. Política Nacional de Promoção da Saúde [Internet]. Brasília; 2006 [citado 2013 out. 25]. Disponível em: http:// portal.saude.gov.br/portal/arquivos/pdf/pactovolume7.pdf

30. Quitério ALD. School physical education: the effectiveness of health-related interventions and recommendations for health-promotion practice. Health Educ J. 2013;72(6):71632.

31. Dobbins M, Husson H, DeCorby K, LaRocca RL. School-based physical activity programs for promoting physical activity and fitness in children and adolescents aged 6-18. Cochrane Database Syst Rev. 2013;(2):CD007651.

32. Brown T, Summerbell C. Systematic review of school-based interventions that focus on changing dietary intake and physical activity levels to prevent childhood obesity: an update to the obesity guidance produced by the National Institute for Health and Clinical Excellence. Obes Rev. 2009;10(1):110-41.
33. National Association of School Nurses (NASN); School Health Nursing Service Role in Health Care. Health promotion and disease prevention [Internet]. Silver Spring; 2004 [cited 2013 Aug 03]. Available from: http://www.orschoolnurse. org/flyers/Student\%20Nurse\%20Resources/Health\%20Promotion\%20and\%20Disease\%20Prevention.pdf

34. Angelo JK, Egan R, Reid K. Essential knowledge for family caregivers: a qualitative study. Int J Palliat Nurs. 2013;19(8):383-8.

35. Klein J, Sendall MC, Fleming M, Lidstone J, Domocol M. School nurses and health education: the classroom experience. Health Educ J. 2013;72(6):708-15.

36. Oliveira HM, Gonçalves MJF. Educação em saúde: uma experiência transformadora. Rev Bras Enferm. 2004;57(6):761-3.

37. Serra-Majem L, Bautista-Castaño I. Etiology of obesity: two "key issues" and other emerging factors. Nutr Hosp. 2013;28 Suppl 5:32-43.

38. Taddeo PS, Gomes KWL, Caprara A, Gomes AMA, Oliveira GC, Moreira TMM. Acesso, prática educativa e empoderamento de pacientes com doenças crônicas. Ciênc Saúde Coletiva. 2012;17(11):2923-30.

39. Maslow AH. Motivación y personalidad. Barcelona: Sagitário; 1954.

40. Regis V, Ladeia LF, Porto IS. A equipe de enfermagem e Maslow: (in)satisfações no trabalho. Rev Bras Enferm. 2006;59(4):565-8.

41. Bandura A. Social cognitive theory: an agentic perspective. Annu Rev Psychol [Internet]. 2001 [cited 2013 Sept 22];52:126. Available from: http://www.uky.edu/ eushe2/Bandura/ Bandura2001ARPr.pdf

42. Bandura A. A evolução da teoria social cognitiva. In: Bandura A, Azzi RG, Polydoro SA. Teoria social cognitiva: conceitos básicos. Porto Alegre: Artmed; 2008. p.15-42.

43. U.S. Department of Health and Human Services; National Institutes of Health. Theory at a glance, a guide for health promotion practice [Internet]; 2005 [cited 2013 July 15]. Available from: http://www.cancer.gov/cancertopics/cancerlibrary/theory.pdf

44. Rosenstock IM. The health belief model: explaining health behavior through expectancies. In: Glanz K, Lewis FM, Rimer BK. Health behavior and health education: theory, research and practice. San Francisco: Jossey-Bass; 1990. p. 39-62.

45. Prochaska JO, DiClemente CC. Stages and processes of selfchange in smoking: toward an integrative model of change. J Consult Clin Psychol. 1983;51(3):390-5. 
46. Victor JF, Vasconcelos FF, Araújo AR, Ximenes LB, de Araújo $\mathrm{TL}$, Okano HI, et al. Grupo feliz idade: cuidado de enfermagem para a promoção da saúde na terceira idade. Rev Esc Enferm USP [Internet]. 2007 [citado 2013 jul. 29];41(4):72430. Disponível em: http://www.scielo.br/pdf/reeusp/ v41n4/25.pdf

47. Gleddie D. A journey into school health promotion: district implementation of the health promoting schools approach. Health Promot Int. 2012;27(1):82-9.

48. Edelman M, Ficorelli CT. Ending the epidemic of adolescent obesity. Nursing. 2012; 42(11):1-3.

49. Sendall MC, Lidstone J, Fleming M, Domocol M. Nurses and teachers: partnerships for green health promotion. J Sch Health. 2013;83(7):508-13.

50. Kostenius C. Student-driven health promotion activities. Health Educ. 2013;113(5):407-19.
51. Amestoy SC, Backes VMS, Trindade LL, Canever BP. The scientific production regarding leadership in the context of nursing. Rev Esc Enferm USP [Internet]. 2012 [cited 2013 Aug 26];46(1):227-33. Available from: http://www.scielo.br/ pdf/reeusp/v46n1/en_v46n1a30.pdf

52. Cohen B. Barriers to population-focused health promotion: the experience of public health nurses in the province of Manitoba. Can J Nurs Res. 2006;38(3):52-67.

53. Brasil. Ministério da Saúde; Conselho Nacional de Secretários de Saúde. Planificação da Atenção Primária à Saúde nos Estados [Internet]. Brasília: CONASS; 2011 [citado 2013 ago. 26]. Disponível em: http://www.conass.org.br/conassdocumenta/cd_23.pdf

54. Nebot Adell C, Rosales Echevarria C, Borrell Bentz RM. Curso virtual para el desarrollo de competencias en atención primaria de salud. Rev Panam Salud Publica. 2009;26(2):176-83. 